\title{
Multiple supernumerary teeth in a non-syndromic patient: a case report and review of literature
}

Paula Loures Valle Lima ${ }^{\mathrm{a}}$, Francisco Loures Valle Lima ${ }^{\mathrm{b}}$, Christian Giancarlo Bernal-Rodriguez ${ }^{\mathrm{c}}$, Elaine Faga Iglecias ${ }^{c}$, Luciana Fávaro Francisconi-dos-Rios ${ }^{d}$

\begin{abstract}
OBJECTIVE: Supernumerary teeth (ST) are associated with many complications that include tooth impaction, ectopic eruption, and abnormal development of root. The usual treatment is the extraction, although repositioning in the dental arch may sometimes be an alternative. The present study reports the treatment of a case of multiple supernumerary teeth in a non-syndromic patient.

CASE DESCRIPTION: A 16-year-old male patient presented two ST in each side of the mandible, detected by panoramic radiography. Syndromes or systemic diseases were not revealed by the anamnesis/general health history. Cone-Beam Computed Tomography (CBCT) showed that the teeth were positioned in the lingual region between the lower premolars at both right and left sides. Surgical therapy was the treatment of choice, in order to avoid possible eruption.

CONCLUSION: An early and accurate diagnosis is extremely important for treatment decision and success, thus avoiding future complications often related to ST.
\end{abstract}

Keywords: supernumerary teeth; tooth abnormalities; malocclusion; hyperodontia.

\section{Dentes supranumerários múltiplos em paciente não sindrômico: caso clínico e revisão de literatura}

\section{RESUMO}

OBJETIVO: Dentes supranumerários (DS) estão associados a muitas complicações, tais quais impactação, erupção ectópica, e desenvolvimento anormal da raiz. No geral, o tratamento escolhido é a exodontia, embora o reposicionamento na arcada dentária possa ser uma alternativa. O presente estudo reporta o tratamento de um caso de dentes supranumerários múltiplos em um paciente não sindrômico.

RELATO DO CASO: Paciente do sexo masculino de 16 anos de idade apresentou 2 dentes supranumerários em cada lado da mandíbula, detectados por meio de radiografia panorâmica. Doenças sistêmicas e síndromes não foram reveladas pela anamnese e avaliação da história de saúde geral do paciente. A Tomografia Computadorizada Cone-Beam (TCCB) mostrou que os dentes estavam posicionados na região lingual entre os pré-molares inferiores de ambos os lados, direto e esquerdo. A terapia cirúrgica foi o tratamento de escolha, a fim de se evitar possível erupção.

CONCLUSÃO: Um diagnóstico precoce e preciso é extremamente importante para a decisão e o sucesso do tratamento, assim evitando futuras complicações frequentemente relacionadas a DS.

Palavras-chave: dentes supranumerários; anormalidades dentárias; má oclusão; hiperdontia.

\author{
a Pediatric Dentistry Specialist, School of Dentistry, \\ Department of Operative Dentistry, University of São \\ Paulo, São Paulo, Brazil \\ b Private Practice, Implant specialist, Specialty \\ training in maxillofacial surgery and periodontics, \\ São Leopoldo Mandic, Belo Horizonte, Brazil. \\ c School of Dentistry, Department of Operative \\ Dentistry, University of São Paulo, São Paulo, Brazil \\ d Assistant Professor, School of Dentistry, \\ Department of Operative Dentistry, University of \\ São Paulo, São Paulo, Brazil
}




\section{INTRODUCTION}

Hyperodontia is a term used to conceptualize teeth that are observed in addition to the ordinary number [1]. They may occur in any region of the mandible and the maxilla, uni or bilaterally, but are often isolated findings in the premaxilla $[2,3]$. Multiple supernumerary teeth (ST) are uncommon, especially in non-syndromic individuals [1].

The etiology of ST is uncertain, although there are several theories for their occurrence. The phylogenetic reversion process states that the teeth are formed because of local hyperactivity, conditioned by the dental blade [4]. However, Primosch [5] rejected this theory because of ectopic occurrence of ST. Environmental factors, such as tooth germ dichotomy, hyperactivity and location of the independent dental blade are suggested as possible etiological factors [6]. The hyperactivity and the location of the dental lamina are the most accepted causes of the development of those teeth $[5,6]$.

Detection of ST is difficult since most of them do not erupt. Thus, practitioners casually identify these teeth in radiographic examinations indicated for other purposes, such as panoramic radiography. Then, Cone-Beam Computed Tomography (CBCT) can be used to better evaluate the case. CBCT images are clearer and more accurate than conventional dental radiographs, allowing for the identification of the position of the abnormalities and their proximity to important anatomical structures $[2,6,7]$.

Early diagnosis is, by the way, imperative to prevent possible complications derived from the presence of ST, i.e., retention of the adjacent teeth and position changes [7,8]. This would be even more relevant in the case of nonsyndromic patients, in which a deeper examination, including the use of complementary tests, would be necessary. In the present study, we thus report, based upon a literature review, the treatment of a non-syndromic patient presenting multiple supernumerary teeth.

\section{CASE DESCRIPTION}

A 16-year-old male patient presented for routine dental care and possible not erupted third molars extraction. In the anamnesis/general health history, syndromes or systemic diseases were not detected. Medical and familiar history thus revealed unremarkable conditions. The clinical intraoral examination pointed to a dentition without apparent abnormalities.

At the panoramic radiography (Fig. 1A), requested for thorough evaluation of the third molars, 36 teeth could be seen, i.e., besides the 32 normally present, four ST existed in the lower arch: two at the right and two at the left side, next respective premolars. A CBCT (Fig. 1B, C, D, E) of the lower arch was then accomplished to better evaluate ST location, their relationship with the surrounding tissues, and the presence of any possible root resorption of the adjacent teeth. ST were positioned lingually to respective premolars without close proximity to the mandibular canal and the inferior alveolar nerve accordingly.

The extraction was indicated to prevent changes in the occlusion and adjacent teeth root resorption. Avoiding
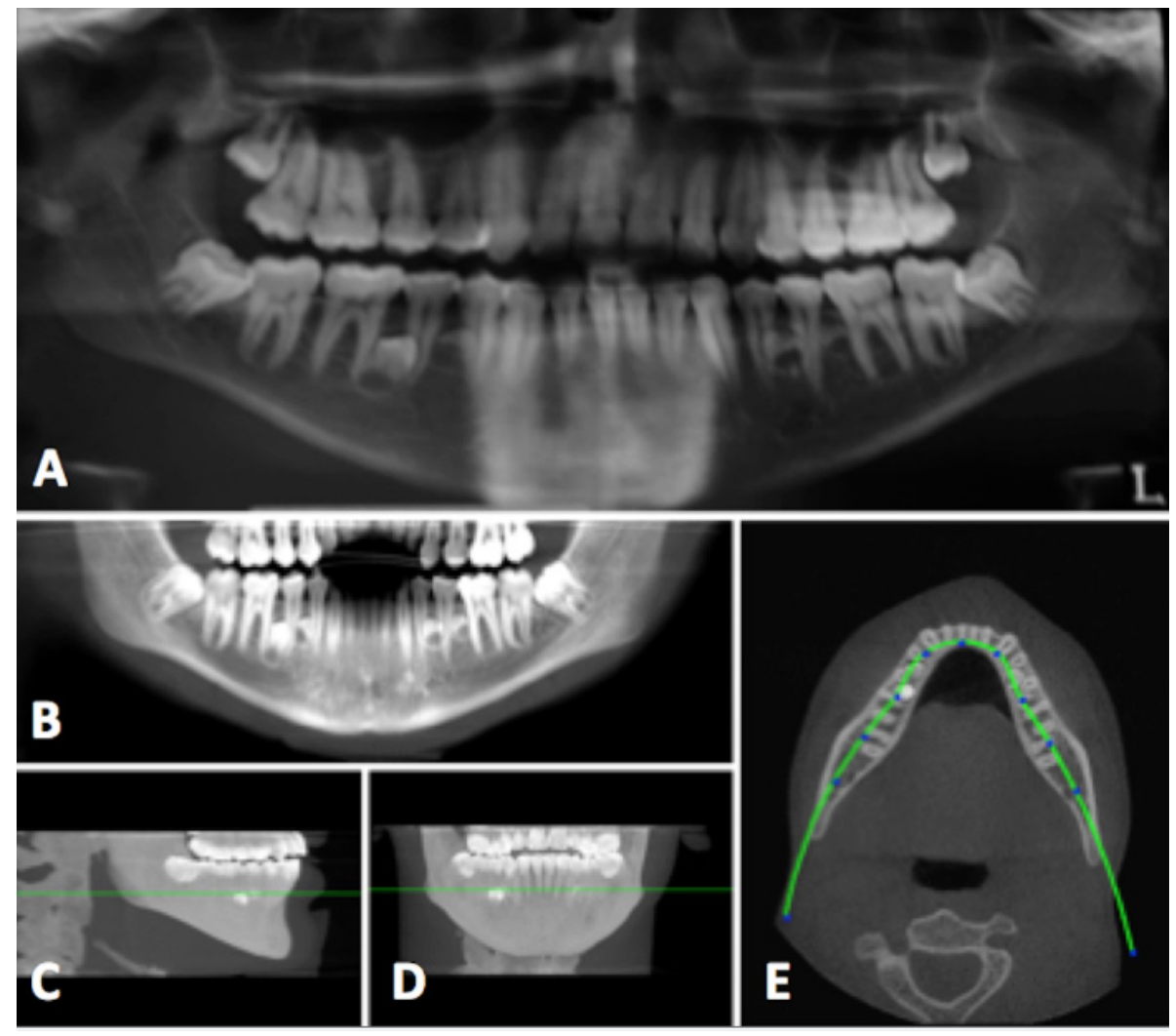

Figure 1. A - Panoramic radiograph for evaluation of the non-erupted third molars, showing four supernumerary teeth in the mandible, two on the left side, and two on the right side, next to corresponding premolars B - Cone-Beam Computed Tomography (CBCT). C, D - Supernumerary teeth without showing close proximity to the mandibular canal (inferior alveolar nerve). E - Supernumerary teeth positioned lingually to respective premolars on both sides of the mandible. 
further damage to contiguous teeth, to surrounding tissues, and maintaining a physiological occlusion favors risk/benefit ratio of extraction compared to follow-up only.

Surgical planning was based upon clinical and complementary exams (panoramic radiography and $\mathrm{CBCT}$ ), so that procedure was the least invasive possible, preserving sound bone. Osteotomy through lingual alveolar bone cortex $(35 \mathrm{~mm}$ round carbide drilling; low rotation; constant irrigation with sterile saline) was performed with local anesthesia (2\% lidocaine with 1:100000 epinephrine/ Alphacaine; Nova $\mathrm{DFL}^{\circledR}$ ), after a mucoperiostal retail (incision with a \#15 sharp sterile scalpel/Lamedid Solidor), and reflecting of the mucoperiosteum with periosteal elevators $\left(\# 9-\right.$ Molt $\left.^{\circledR}\right)($ Fig. 2A, B).
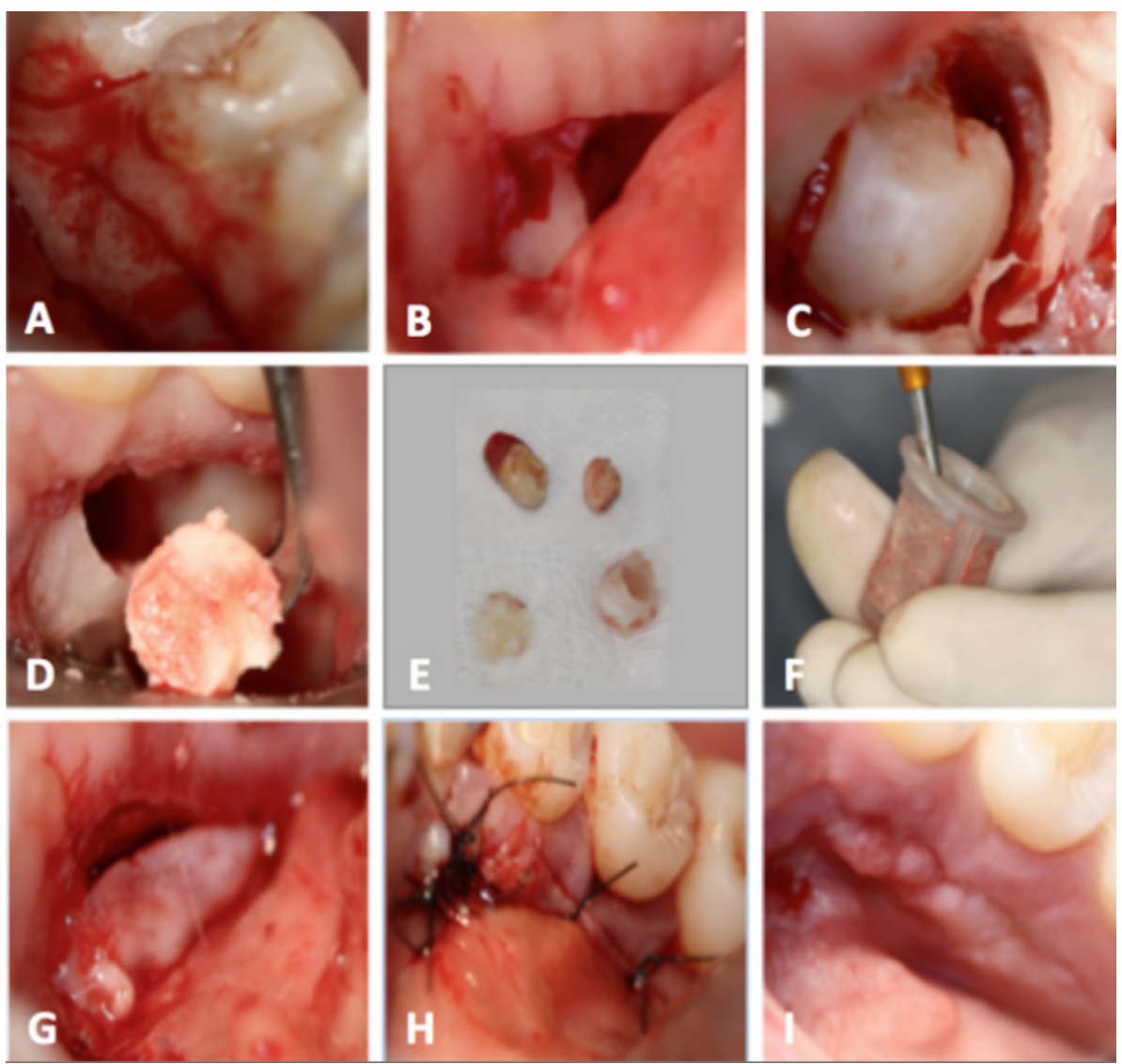

ST were removed through luxation with Warwick James elevators (number 1L, 1R, 2/ Duflex $^{\circledR}$ ) (Fig. 2C, D, E). Periapical curettes $\left(\mathrm{McCall}^{\circledR}, 13-14\right)$ were used to remove soft tissue from bone defects. Bone collected during the procedure was finally adapted in the surgical cavity to hold up effective bone repair (Fig. 2F). Soft tissue was repositioned and X sutured with \#4.0 silk thread $\left(\right.$ Procare $\left.^{\circledR}\right)($ Fig. 2G, H). Suture was removed after seven days of the surgery (Fig. 2I). Patient had no postoperative complications: pain, swelling, paresthesia and/or any infection.

After one month of the procedure, a new panoramic radiography revealed no impairments in the related region (Fig. 3); thermal testing showed premolars were vital.
Figure 2. A - Incision and

determination of mucoperiosteal flap. B - Alveolar osteotomy in the lingual bone cortex. C - Exposure of nonerupted supernumerary teeth. D - Teeth extraction. E - Extracted supernumerary teeth. $\mathbf{F}$ - Bone collector. G - Shop surgery with tissue replacement. H - Surgical sites sutured with \#4.0 silk thread. I - Tissue repair after 7 days of surgery. 


\section{DISCUSSION}

Supernumerary teeth are anomalies that result in excessive number of teeth. Many authors have suggested inheritance as a key factor in their development [4].

An increased prevalence of supernumerary teeth can be found in cleft lip and palate patients, and there are over 20 syndromes (Gardner and Down syndromes, Cleidocranial dysplasia) associated with the presence of ST [3, 9, 10,11]; they are thus rare in nonsyndromic individuals $[5,9]$. Most accepted explanation to these cases is the dental lamina hyperactivity theory $[4,5,12]$. According to it, a supplemental form would develop from the lingual extension of an accessory tooth bud, whereas a rudimentary form would develop from the proliferation of epithelial remnants of the dental lamina $[4,5,12]$. In bilateral supernumerary teeth cases, it is more likely, however, that they develop concurrently with the natural permanent teeth and have complete root formation athwart the lingual extensions during the time that the molecular signals for the bilateral distribution of successional permanent tooth buds are active $[13,14]$. In addition, they are commonly found in the anterior maxillary area and in the lower premolar region $[9,13,14]$.

Frequencies of their occurrence in the referred places are of $90 \%$ and $6 \%$, respectively [11]; in most non-syndromic patients, yet, the total number of ST is higher than $5[4,6]$.

ST usually have abnormal morphologies (conical, tubercular) [10] and are atypically located (mesiodens, paramolar, distomolar) [15]. ST found in this case report were classified as conical, rudimentary, paramolar, hence.

Complications associated with ST include delayed eruption/noneruption, crowding or displacement, tooth rotation, diastema, retention of deciduous teeth, and resorption of neighboring teeth, in $50.8 \% / 88.5 \%, 55.7 \%$, $28.7 \%, 21 \%, 7.9 \%$, and $0.3 \%$ of cases, respectively [15]. Nevertheless, any discernable side effects were related to $\mathrm{ST}$ in the present case, very likely because early diagnosis and proper treatment.

By the way, the diagnosis was based upon incidental findings from a "routine" radiographic examination. Evidently that the panoramic radiography played a crucial role as a first tool in the sense, but its limitations, such as overlapping of anatomical structures, must be acknowledged. [6,7]. Improved imaging techniques are thus needed to determine ST exact location and their proximity to neighboring anatomical structures [7,8]. In recent years, it has been possible to obtain 3D (axial, coronal and sagital) images of oral structures [7] by high resolution CBCT. Clearer and understandable images of the regions analyzed allow the measurement of diverse structures and even the distance between them in accordance with facial anatomical configuration $[7,8]$. They are thus useful for determining, among other treatment details, a buccal or a lingual access for extraction of the ST [8].

Once ST have been identified, extracting or monitoring are the two usual possibilities to deal with them. The advantages and disadvantages of both options are to be given attention, and a final decision has to account the risk/ benefit relationship of the surgical removal. The surgical removal is not free of risks; extraction of impacted teeth may lead to damage of the adjacent structures and/or teeth with possible ankyloses [5]. Hence, only when the benefits of removal overbalance the risks of a surgery is that extraction turns out to be the treatment of choice. Anyway, there is no consensus on the best time for the surgical removal of a non-erupted ST $[1,15]$. Omer et al. [1] have suggested that the therapeutic option that causes minor complications is the surgical removal of impacted ST when the permanent teeth are in the stage $\mathrm{C}$ of the Demirjian classification of dental development: enamel formation is complete at the occlusal surface, dentine deposition has started and the pulp chamber has a curved shape at the occlusal border. Given the advanced time in the sense, ST in the present case, already formed and with mineralized crowns, were extracted as soon as possible, and treatment proved successful regardless of adjacent teeth complete root formation (stage $\mathrm{H}$ of the Demirjian classification of dental development: the apical end of the root is completely closed and the periodontal membrane has a uniform width around the tooth apex).

\section{CONCLUSION}

$\mathrm{CBCT}$ as an adjunct to radiographic examination has fundamental importance to early and accurate diagnosis, evaluation and treatment decision related to ST in nonsyndromic patients. Extraction may be the treatment of choice, thus avoiding undesirable complications.

\section{REFERENCES}

1. Omer RS, Anthonappa RP, King NM. Determination of the optimum time for surgical removal of unerupted anterior supernumerary teeth. Pediatr Dent 2010;32:14-20

2. Nematolahi H, Abadi H, Mohammadzade Z, Soofiani Ghadim M. The use of Cone Beam Computed Tomography (CBCT) to determine supernumerary and impacted teeth position in pediatric patients: a case report. J Dent Res Dent Clin Dent Prospects 2013;7:47-50

3. Tereza GP, Carrara CF, Costa B. Tooth abnormalities of number and position in the permanent dentition of patients with complete bilateral cleft lip and palate. Cleft Palate Craniofac J 2010;47:247-52. https://doi. org/10.1597/08-268.1

4. Smith JD. Hyperdontia: Report of a case. Journal of the American Dental Association 1969;79:1191-2. https://doi.org/10.14219/jada. archive.1969.0068

5. Primosch RE. Anterior supernumerary teeth - Assessment and surgical intervention in children. Pediatr Dent 1981;3:204-15.

6. Liu JF. Characteristics of premaxillary supernumerary teeth: a survey of 112 cases. ASDC Journal of Dentistry for Children 1995;62:262-5.

7. Sherrard JF, Rossouw PE, Benson BW, Carrillo R, Buschang PH. Accuracy and reliability of tooth and root lengths measured on cone-beam computed tomographs. Am J Orthod Dentofacial Orthop 2010;137(4):S100-S108. https://doi.org/10.1016/j.ajodo.2009.03.040

8. Liu DG, Zhang WL, Zhang ZY, Wu YT, Ma XC. Three-dimensional evaluations of supernumerary teeth using cone-beam computed tomography for 487 cases. Oral Surg Oral Med Oral Pathol Oral Radiol Endod 2007;103: 403-11. https://doi.org/10.1016/j.tripleo.2006.03.026

9. Moore SR, Wilson DF, Kibble J. Sequential development of multiple supernumerary teeth in the mandibular premolar region - a radiographic case report. Int J Paediatr Dent 2002;12:143-5. https://doi.org/10.1046/ j.1365-263X.2002.00336.x 
10. Luten JR. The prevalence of STin primary and mixed dentitions. ASDC Journal of Dentistry for Children. 1967;34:346-53.

11. Parolia A, Kundabala M, Dahal M, Mohan M, Thomas MS. Management of supernumerary teeth. J Conserv Dent 2011;14:221-4. https://doi. org/10.4103/0972-0707.85791

12. Syriac G, Joseph E, Rupesh S, Philip J, Cherian SA, Mathew J. Prevalence, Characteristics, and Complications of Supernumerary Teeth in Nonsyndromic Pediatric Population of South India: A Clinical and Radiographic Study. J Pharm Bioallied Sci 2017 Nov;9(Suppl 1): S231-S236. https://doi.org/10.4103/jpbs.JPBS 15417

13. Wang XP, Fan J. Molecular genetics of supernumerary tooth formation. Genesis 2011;49:261-7. https://doi.org/10.1002/dvg.20715
14. Jain P, Kaul R, Saha S. Rare molariform supernumerary teeth: Why are they bilateral? Indian J Dent Res 2017 Nov-Dec;28(6):702-5. https://doi. org/10.4103/ijdr.IJDR 24217

15. Kara Mi, Aktan AM, Ay S, Bereket C, Şener I, Bülbül M, Ezirganlı Ş, Polat HB. Characteristics of 351 supernumerary molar teeth in Turkish population. Med Oral Patol Oral Cir Bucal 2012;17:e395-400. https://doi. org/10.4317/medoral.17605 